\title{
Respiratory symptoms in Danish farmers: an epidemiological study of risk factors
}

\author{
MARTIN IVERSEN, RONALD DAHL, JENS KORSGAARD, THORKIL HALLAS, \\ ERIK JUEL JENSEN
}

From the Department of Respiratory Diseases, University Hospital of Aarhus, and the Danish Pest Infestation Laboratory, Copenhagen, Denmark

ABSTRACT An epidemiological study was performed with a self administered questionnaire in a representative sample of 1685 Danish farmers. The purpose of the study was to assess the prevalenceᄋ of self reported asthma, wheezing during work, and symptoms of chronic bronchitis and to evaluate possible risk factors for the development of these symptoms. A response rate of $73.3 \%$ was obtained. $Z$ The prevalence of asthma was $7 \cdot 7 \%$ and of chronic bronchitis $23.6 \%$ in responders. The prevalence of asthma and chronic bronchitis increased from $3.6 \%$ and $17.9 \%$ in $31-50$ year old farmers to $11.8 \%$ and $33.0 \%$ in $51-70$ year old farmers, and from $5.5 \%$ and $17.5 \%$ in dairy farmers to $10.9 \%$ and $32.0 \%$ 东 in pig farmers. A logistic regression analysis with correction for age and smoking habits confirmed $\overrightarrow{0}$ that pig farming was a risk factor for asthma (odds ratio 2.03), chronic bronchitis (odds ratio 1.53), $\infty$ and wheezing during work (odds ratio 3.33).

\section{Introduction}

Epidemiological studies have shown a high frequency of respiratory symptoms in farmers. Symptoms of chronic bronchitis have been found to have a much higher frequency in farmers than in a non-farming population and bronchial obstruction has been found to occur much more frequently than expected..$^{1-6}$ Some studies have pointed to pig farming as a particular risk factor for respiratory symptoms. ${ }^{78} \mathrm{~A}$ high prevalence of asthma has been reported in farmers, and in cases of allergic asthma the predominant cause was storage mites. ${ }^{10}$

This study was undertaken to assess the prevalence of respiratory symptoms in Danish farmers and more specifically to look for risk factors for the development of respiratory symptoms.

\section{Methods}

\section{STUDY POPULATION}

The study population consisted of all 1685 members of the farmers' association in three municipalities in the county of Aarhus, Denmark. Farming in the area is mainly dairy farming, pig farming, or a mixture of these. Farms are small to medium sized and $88 \%$ of cultivated land is on farms smaller than 50 hectares. This is similar to the national average. A questionnaire $\stackrel{\mathbb{D}}{\circ}$ was issued by post to all farmers.

\section{QUESTIONNAIRE}

The questionnaire contained questions on personalo characteristics - that is, age, smoking habits, and full $\vec{F}$ time or part time employment on the farm, and on the 을 area of the farm and the type of farm (pig farming, $\tilde{x}$ dairy farming, or no animals). Questions on res- 0 piratory symptoms included the questions "Do you have asthma?";“Do you have hay fever?";“'Do you 0 have periods with shortness of breath, dry cough, or wheezing?";"'Do you have shortness of breath, cough, 음 or wheezing when working in the stable, during work $\square$ with grain etc?" The question about the occurrence of chronic bronchitis was "Do you have cough and bring N up phlegm on most days, especially in the morning?"

\section{RESPONDERS AND NON-RESPONDERS}

Of the 1685 questionnaires, 1222 were returned. Only무 1175 questionnaires were valid as two farmers refusedo to participate, 17 had retired years before, and $28 \AA$ could not be identified. This gives a crude response? rate of $70.4 \%$. One reminder was issued to achieve this 7 response rate.

Among the 463 non-responders a random sample of $\stackrel{\overparen{D}}{\stackrel{\mathbb{D}}{ }}$ 50 was chosen and a telephone interview was conduc- $\mathbb{Q}$ ted to obtain answers to the questionnaire. None 
refused to participate. Five had already answered the questionnaire because of membership of the farmers' association in two municipalities and two were not active farmers but only passive members of the farmers' association. With these corrections the response rate was $73 \cdot 3 \%$. There was no difference between responders and non-responders with respect to age, type of farming, number of hectares, part time versus full time work on the farm, smoking habits, or symptoms of bronchitis and hay fever. There was, however, no case of known asthma in the sample of non-responders and when this was compared with the frequency of asthma in the responders (table 1) the difference was significant ( $p<0.05, \chi^{2}$ test).

The 1175 valid questionnaires were included in the analysis. Forty six of the respondents $(3.9 \%)$ had retired during the previous year. They were included in the analysis because they had had many years of exposure during farm work. All 1175 respondents were male.

\section{STATISTICAL ANALYSIS}

Analyses of simple two dimensional contingency tables were performed with SPSS. " Further analyses with stratification were performed with the method of Mantel and Haenszel. ${ }^{12}$ Finally, a multivariate analysis was performed on some variables by the method of logistic regression. ${ }^{13}$

Table 1 Diseases and symptoms (\%) in the 1175 farmers who responded to the questionnaire

\begin{tabular}{lr}
\hline Hay fever & $9 \cdot 4$ \\
Asthma & $7 \cdot 7$ \\
Treatment for asthma & $3 \cdot 5$ \\
Atopy in first degree relatives (asthma, hay fever, eczema) & 22.6 \\
Daily cough and phlegm & 23.6 \\
Periods of shortness of breath & $13 \cdot 7$ \\
$\quad$ wheezing & $16 \cdot 3$ \\
$\quad$ dry cough & 22.1 \\
\hline
\end{tabular}

Results

RESULTS WITHOUT STRATIFICATION

Eight hundred and eight of the farmers $(68 \cdot 8 \%)$ were employed full time on the farm and $321(27 \cdot 3 \%)$ part time, and 46 were retired. Two hundred and thirty five $(20 \%)$ had only grain production and $316(26.9 \%)$ had pig farming and dairy farming, $203(17 \cdot 3 \%)$ having exclusively dairy farming and $369(31.4 \%)$ exclusively pig farming; $52(4.4 \%)$ could not be classified. Four hundred and twenty seven $(36.8 \%)$ were smokers and $36(3 \cdot 1 \%)$ did not answer the question about smoking. The age distribution was: $8.7 \% \leqslant 30$ years, $39.7 \% 31-$ 50 years, $42 \cdot 1 \% 51-70$ years, and $9 \cdot 5 \%>70$ years.

The frequencies of symptoms and diseases are given in table 1.

\section{EFFECT OF AGE}

The farmers were subdivided into four age groups and the relation of age to other variables was investigated in a two dimensional table (table 2). A strong association was found with age for most variables. Smoking, which was not associated with age on a dichotomous scale ( $<50$ years, $\geqslant 50$ years), was found to be weakly associated with age in this further subdivision in age groups. In the age groups from 31 to 70 years $(81.8 \%$ of farmers) there was no difference in the frequency of smoking. For other variables there was an increase with age. For asthma, symptoms of bronchitis, and symptoms such as wheezing and shortness of breath the increase was pronounced and highly significant. For cough without production of phlegm there was no difference between age groups.

\section{EFFECT OF TYPE OF FARMING}

To explore the effect of type of farming on symptoms the farmers were divided into four groups with respect to animal production. Table 3 shows that most farmers with no animal production were part time farmers. There was a strong gradient for most symptoms, with a gradual increase from dairy farmers to dairy farmers with pig farming to farmers with

Table 2 Diseases and symptoms (\%) in 1175 farmers by age

\begin{tabular}{|c|c|c|c|c|c|}
\hline \multirow[b]{2}{*}{$(n)$} & \multicolumn{4}{|c|}{ Age (y) } & \multirow[b]{2}{*}{${ }^{p}\left(\chi^{2}\right.$ test $)$} \\
\hline & $\begin{array}{l}\leqslant 30 \\
(102)\end{array}$ & $\begin{array}{l}31-50 \\
(466)\end{array}$ & $\begin{array}{l}51-70 \\
(495)\end{array}$ & $\begin{array}{l}>70 \\
(112)\end{array}$ & \\
\hline $\begin{array}{l}\text { Asthma } \\
\text { Treatment for asthma } \\
\text { Cough and daily production of phlegm } \\
\text { Smoking } \\
\text { Shortness of breath } \\
\text { Wheezing } \\
\text { Dry cough } \\
\text { Shortness of breath, dry cough or wheezing during } \\
\text { work in stable }\end{array}$ & $\begin{array}{r}1.0 \\
0.0 \\
10.4 \\
33.0 \\
3.7 \\
6.3 \\
22.6\end{array}$ & $\begin{array}{r}3.6 \\
2.0 \\
17.9 \\
39.6 \\
14.7 \\
15.6 \\
28.1\end{array}$ & $\begin{array}{r}11.8 \\
5.5 \\
33.0 \\
39.4 \\
21.8 \\
27.4 \\
29.7\end{array}$ & $\begin{array}{r}17 \cdot 3 \\
5 \cdot 6 \\
34 \cdot 3 \\
24 \cdot 3 \\
28 \cdot 7 \\
33 \cdot 3 \\
30 \cdot 8\end{array}$ & $\begin{aligned}< & 0.01 \\
< & 0.01 \\
< & 0.01 \\
& 0.01-0.05 \\
< & 0.01 \\
< & 0.01 \\
\text { NS } & \\
< & 0.01\end{aligned}$ \\
\hline
\end{tabular}


Table 3 Relation of type of farming to age, smoking, and symptoms (\%)

\begin{tabular}{|c|c|c|c|c|c|}
\hline \multirow[b]{2}{*}{$(n)$} & \multicolumn{4}{|c|}{ Type of farming } & \multirow[b]{2}{*}{${ }^{p}\left(\chi^{2}\right.$ test $)$} \\
\hline & $\begin{array}{l}\text { No animals } \\
\text { (287) }\end{array}$ & $\begin{array}{l}\text { Dairy } \\
(203)\end{array}$ & $\begin{array}{l}\text { Dairy and pig } \\
(316)\end{array}$ & $\begin{array}{l}\text { Pig } \\
\text { (369) }\end{array}$ & \\
\hline $\begin{array}{l}\text { Age over } 50 \\
\text { Full time employment on farm } \\
\text { Hay fever } \\
\text { Asthma } \\
\text { Treatment for asthma } \\
\text { Cough and daily production of phlegm } \\
\text { Shortness of breath } \\
\text { Wheezing } \\
\text { Dry cough } \\
\text { Smoking }\end{array}$ & $\begin{array}{r}53 \cdot 8 \\
37 \cdot 8 \\
8 \cdot 1 \\
7 \cdot 5 \\
2 \cdot 2 \\
18.6 \\
14 \cdot 4 \\
16 \cdot 0 \\
22 \cdot 8 \\
35 \cdot 1\end{array}$ & $\begin{array}{r}43 \cdot 1 \\
88 \cdot 5 \\
7 \cdot 6 \\
5 \cdot 5 \\
1 \cdot 5 \\
17 \cdot 5 \\
12 \cdot 5 \\
13 \cdot 5 \\
20 \cdot 6 \\
41 \cdot 9\end{array}$ & $\begin{array}{r}65 \cdot 8 \\
77 \cdot 8 \\
9 \cdot 6 \\
6 \cdot 4 \\
3 \cdot 6 \\
28 \cdot 4 \\
19 \cdot 0 \\
27 \cdot 1 \\
28 \cdot 2 \\
37 \cdot 1\end{array}$ & $\begin{array}{r}54 \cdot 5 \\
81 \cdot 4 \\
13 \cdot 3 \\
10 \cdot 9 \\
5 \cdot 3 \\
32 \cdot 0 \\
23 \cdot 1 \\
26 \cdot 2 \\
37 \cdot 2 \\
35 \cdot 7\end{array}$ & $\begin{array}{l}<0.01 \\
<0.01 \\
\text { NS } \\
\text { NS } \\
\text { NS } \\
<0.01 \\
<0.01 \\
<0.01 \\
<0.01 \\
\text { NS }\end{array}$ \\
\hline $\begin{array}{l}\text { Symptoms (shortness of breath, } \\
\text { wheezing, or cough) during work } \\
\text { in animal house }\end{array}$ & - & $7 \cdot 4$ & 11.6 & $28 \cdot 3$ & $<0.01$ \\
\hline
\end{tabular}

exclusively pig farming. Farmers with no animal production were in most respects like dairy farmers. Generally the frequency of hay fever, asthma, and respiratory symptoms such as wheezing or shortness of breath were twice as high in pig farmers as in dairy farmers.

\section{RELATIONS BETWEEN VARIABLES}

To study the relations between respiratory symptoms and pig farming in more detail farmers with animal production were divided into those who worked with pigs and those who did not. Only those who had answered all questions on age, smoking, asthma, and work related symptoms (work in animal house) were included in the analysis. The relations between variables are given in table 4. Pig farming was not

Table 4 Relation between pig production, history of smoking (current smoker, non-smoker), age over 50, and self reported asthma: data from 764 farmers with animal production (odds ratios with significance values of $2 \times 2$ tables in parentheses ( $\chi^{2}$ test $)$ )

\begin{tabular}{llll}
\hline & $\begin{array}{l}\text { Current } \\
\text { smoking }\end{array}$ & Age over 50 & Asthma \\
\hline Pig farming & $0.87(0.32)$ & $0.90(0.47)$ & $1.92(0.01)$ \\
Current smoking & & $0.95(0.68)$ & $\begin{array}{l}1.28(0.27) \\
\text { Age over 50 }\end{array}$ \\
\hline
\end{tabular}

significantly associated with current smoking or age over 50 . Without stratification the relation between symptoms (shortness of breath, wheezing, or cough) during work in the animal house and pig farming gave a highly significant $(p=0.00)$ odds ratio of 3.41 . Stratification with the Mantel-Haenzsel test for age, asthma, and smoking habits did not change the odds ratio significantly. The odds ratio for the relation between smoking and symptoms during work was 1.94 $(p=0.00)$ and was not changed significantly after stratification for other variables. The odds ratio for the relationship between symptoms during work and age $(<50, \geqslant 50$ years) was $1.61(p=0.02)$. Stratification for smoking, pig farming, and asthma reduced the odds ratio to $1 \cdot 14(\mathrm{p}=0.58)$. This analysis therefore showed that pig farming was associated with an increased frequency of asthma, symptoms of bronchitis, and wheezing during work, which could not be explained by differences in age or smoking habits.

\section{MULTIVARIATE ANALYSIS}

A multivariate analysis with a logistic regression program was performed with asthma, bronchitis, and symptoms during work in the animal house as response variables (table 5).

\section{Self reported asthma}

Age and pig farming were significant risk factors for

Table 5 Logistic regression analysis with self reported asthma, symptoms of chronic bronchitis, and respiratory symptoms during work as response variables: data from 764 farmers $*$

\begin{tabular}{lllll}
\hline Response variable & Constant & Age & Smoking & Pig farming \\
\hline Asthma & 0.02 & $5.84(2.80-12.19)$ & $1.44(0.84-2.45)$ & $2.03(1.19-3.46)$ \\
$\begin{array}{l}\text { Symptoms of chronic bronchitis } \\
\begin{array}{l}\text { Wheezing, shortness of breath or cough } \\
\text { during work in animal houses }\end{array}\end{array}$ & 0.12 & $2.51(1.78-3.55)$ & $2.38(1.71-3.30)$ & $1.53(1 \cdot 10-2.13)$ \\
\end{tabular}

*Age ( $\leqslant 50,>50 \mathrm{y}$ ), smoking (yes/no), and pig farming (yes/no) are predictor variables. The constant (intercept) is the odds for disease when all predictor variables are negative ${ }^{13}$; values are odds ratios and $95 \%$ confidence limits in parentheses. 
self reported asthma with odds ratios of 5.84 and 2.03 , whereas smoking was not a significant risk factor. When the interaction term between smoking and pig farming was included in the analysis, it gave an odds ratio of 2.84 and was close to being significant $(p=$ $0.057)$. In the regression model with the interaction term the odds ratio for age and self reported asthma was unchanged whereas the odds ratios for smoking and pig farming decreased to 0.81 and 1.30 , the latter becoming non-significant. The interaction term implies a synergistic effect between smoking and pig farming for the development of asthma.

\section{Bronchitis}

Age, smoking, and pig farming were all significant risk factors for symptoms of chronic bronchitis. No significant interactions were found.

\section{Symptoms during work in animal house}

Smoking and pig farming were found to be risk factors for symptoms of shortness of breath, wheezing, or cough during work in animal houses, with odds ratios of 2.17 and 3.33. Age was not significant as a risk factor in this model. No significant interactions were found.

In this multivariate analysis age was the most important risk factor for the presence of asthma and bronchitis. Current smoking was an independent risk factor for bronchitis and wheezing during work. A synergistic effect between smoking and pig farming could partly explain the increased frequency of asthma in pig farmers. Pig farming was an independent risk factor for bronchitis and of wheezing during work and was the most important risk factor for wheezing during work.

\section{Discussion}

The purpose of this study was to evaluate the frequency of respiratory symptoms among farmers, and to find possible risk factors for the development of symptoms.

Because membership of the farmers' association was the criterion for participation in the study, all large and medium sized farms in the three municipalities were included. As farmers with very small farms (under 10 hectares) are not usually members of the farmers' association they were not included. The ratio of small to large farms in the present study corresponds to the nationwide average and the study population was a representative sample of Danish farmers.

A possible bias might exist in reporting of symptoms, so that those with symptoms would be more likely to respond to the questionnaire. This appeared only for the diagnosis of asthma, where the random sample of non-responders showed no case of asthma in contrast to a prevalence of $7 \cdot 7 \%$ in the study population. Asthma, with its more troublesome symptoms, may therefore have influenced the response rate.

Two forms of selection bias might exist in this study. The first is that young people with obvious allergy might not enter farming, and the second is the "healthy worker effect"- that is, that those with health problems leave the occupation, so that the study population in a cross sectional study consists only of the most healthy people. We cannot estimate the effects of these possible biases. From personal communications with farmers in the study population we know that some of them had given up pig farming because of respiratory complaints.

No standardised questionnaire exists to identify persons with asthma ${ }^{14}$ but in some countries, ${ }^{15}$ including Denmark, there is a very high correlation between self reported asthma and a medical diagnosis of asthma. The asthma frequency of $7 \cdot 7 \%$ of asthma seemed high but was similar to that in the study of van Hage-Hamsten in Swedish farmers. ${ }^{10}$ Because the frequency of self reported asthma was highly dependent on age in the present study, it could not be compared directly with the frequency in epidemiological studies in farmers where no details of age distribution were given. An epidemiological study $^{16}$ of a representative sample of the Danish population used the same question about asthma as we did and, as details of age distribution were available, we can compare the frequency of asthma in the two studies. There was no difference in the frequency of asthma for subjects aged $30-49$ years ( $p>0 \cdot 1, \chi^{2}$ test). For subjects in the age group 50-69 years there was a much higher frequency of asthma in the present study. The odds ratio for having asthma was 2.25 (p < 0.001) when farmers aged 50-69 years were compared with the representative sample of the Danish population of similar age.

Age in this study also reflects the number of years in the occupation. With a few exceptions all farmers in this study were raised on a farm and had worked in farming since their youth. The number of years of full time employment in farming was approximately age minus 15 years.

In this study both age and pig farming were risk factors for self reported asthma. An interaction between smoking and pig farming seemed to exist. Pig farming has been associated with an increased risk of chronic wheezing and cough ${ }^{7}$ and has been shown to produce acute wheezing during work in animal houses ${ }^{6}$ but has not been associated with an increased frequency of self reported asthma as in this study.

For reasons of simplicity questions on smoking habits and symptoms of bronchitis were kept to a 
minimum. Ex-smokers were included as non-smokers and subjects were divided into current non-smokers and daily smokers. The question on bronchitis asked for daily cough with production of phlegm, especially in the morning. These questions would tend to weaken a possible relation between risk factors and symptoms, so their simplified design does not invalidate the conclusions from this study. Age over 50, smoking, and pig rearing were risk factors for bronchitis. Mucus hypersecretion (simple bronchitis) and chronic airways obstruction are considered as different entities, although smoking is a risk factor for both. ${ }^{17}$ Smoking has also been found to be a risk factor for respiratory symptoms and airways obstruction in rural populations. ${ }^{1819}$

For symptoms such as shortness of breath, wheezing, and cough without production of phlegm both smoking and pig rearing were risk factors. This is in accordance with the cross sectional study of Donham, which included farmers with pig rearing units with large numbers of animals, whereas many farmers in the present study would be exposed during work in pig rearing units only for two to four hours each day. Working in pig rearing units ${ }^{6}$ has been shown to cause an acute decrease in FEV and forced vital capacity both in farmers and in control subjects. The reason for this is not known, but many possibilities exist. Relatively high levels of organic dust in farm buildings and especially in pig rearing units have been reported in several studies. ${ }^{20-23}$ With personal sampling in the breathing zone total organic dust concentrations range from 5 to $10 \mathrm{mg} / \mathrm{m}^{3}$ of air. The respirable fraction ranges from $5 \%$ to $50 \%$, presumably because of different techniques of measurement. Some controversy exists about the origin of the organic dust in pig rearing buildings. The dust has a high protein content, ${ }^{24}$ the dust concentration is closely associated with the activity of the animals, ${ }^{21}$ and spraying the animals with oil reduces the total organic dust concentration by $80 \%$ for four days. ${ }^{25}$ This supports the hypothesis that a substantial part of the dust is of animal origin.

Immunological studies ${ }^{2627}$ have shown that IgE antibodies to animal (swine) proteins occur rarely and have no association with symptoms. To our knowledge only one case of asthma caused by allergy to swine protein verified by bronchial challenge has been reported. ${ }^{28}$ Allergy to storage mites occurs in $12 \%$ of farmers, but only a quarter of asthmatic farmers have an allergy to storage mites. ${ }^{10}$

Other potential harmful substances have been identified in the air in pig rearing buildings. Fungi and bacteria are consistently found in high numbers, ranging from $10^{4}$ to $10^{6} / \mathrm{m}^{3}$ of air. The ammonia concentration is often $10-20 \mathrm{ppm},{ }^{23}$ but much higher concentrations - up to $200 \mathrm{ppm}$ - have been found during the winter ${ }^{29}$ Hydrogen sulphide appears only $\stackrel{?}{?}$ sporadically ${ }^{23}$ and in low concentrations. Endotoxin activity has been reported in dust from pig rearing $\frac{\bar{\sigma}}{\bar{N}}$ units in concentrations that might cause respiratory $\frac{\bar{\sigma}}{\vec{\sigma}}$ symptoms, ${ }^{22}{ }^{23}$ but concentrations have usually been $\odot$ reported as low.

A wide range of bacteria has been shown to cause $\vec{\circ}$ histamine release from human lung cells by a non-IgE:dependent mechanism. ${ }^{30}$ Grain dust extracts have been $\vec{\omega}$ shown to cause release of histamine and leukotrienes from human lung tissue by a non-immunological $\vec{x}$ mechanism. ${ }^{31}$ This mechanism has been suspected as $t$ the cause of acute bronchoconstriction in some grain $\rightarrow$ workers. The relevance of this and other mechanisms $\overrightarrow{\dot{\infty}}$ for the development of respiratory symptoms in farm $N$ workers has yet to be evaluated. The present study has 0 confirmed the finding of earlier studies that pig farming is associated with chronic wheezing and $z$ symptoms of chronic bronchitis. For the first time it $\bigcirc$ has been recognised that pig farming is associated with $\stackrel{\oplus}{3}$ a risk for the development of self reported asthma. Further studies are necessary to determine whether this is causally related to the high load of respirable $\overrightarrow{0}$ dust and to what extent special properties of dust oro toxic gases are responsible for the risk of developing asthma.

\section{References}

1 Warren CPW, Manfreda J. Respiratory symptoms in Manitoba farmers: Association with grain and hay handling. Can Med Assoc J 1980;122:1259-64.

2 Warren CPW. Respiratory symptoms in Manitoba cattle farmers. Can Med Assoc J 1981;125:41-6.

3 Pariente R, Couland C, Fagnani F. Etude de la frequence des bronchiopathies chroniques en milieu agricole. Rev응 Fr Mal Respir 1976;4:61-73.

$4 \mathrm{Katila}$ ML. Respiratory disease in a farming population. Thesis, University of Kuopio, Finland, 1979.

5 Dosman JA, Graham BL, Hall D, Loom P Van, Bhai P, Froh F. Respiratory symptoms and pulmonary function in farmers. Journal of Occupational Medicine 1987; 응 29:38-43.

6 Husman K, Koskenvuo M, Kaprio J, Terho EO, D Vohlonen I. Role of environment in the development of chronic bronchitis. Eur J Respir Dis 1987;71(supplN 152):57-63.

7 Donham KJ, Zavala DC, Merchant JA. Respiratory N symptoms and lung function among workers in swine confinement buildings: a cross sectionalo epidemiological study. Arch Environ Health 1984;39:96-100.

8 Donham KJ, Zavala DC, Merchant JA. Acute effects of the work environment on pulmonary functions of swine confinement workers. Am J Ind Med 1984;5: $\frac{0}{0}$ 367-75.

9 Cuthbert OD, Jeffrey IG, McNeill HB, Wood J, Topping $\stackrel{\mathbb{D}}{\varrho}$ MD. Barn allergy among Scottish farmers. Clin Allergy $\mathbb{\Phi}_{\triangle}$ 1984;14:197-206. 
10 Van Hage-Hamsten M, Johansson SGO, Höglund S, Tüll $\mathbf{P}$, Wiren A, Zetterström $\mathbf{O}$. Storage mite allergy is common in a farming population. Clin Allergy 1985;15: 555-64.

11 Nie NH, Hull CH, Steinbrenner K, Bent DH. SPSS, Statistical package for the social sciences. New York: McGraw Hill, 1975.

12 Mantel N, Haenszel W. Statistical aspects of the analysis of data from retrospective studies of disease. $J$ Natl Cancer Inst 1959;22:719-48.

13 Breslow NE, Day NE. Statistical methods in cancer research. Vol 1. The analysis of case control studies. Lyon: International Agency for Research in Cancer, 1980. (IARC scientific publications No 32.)

14 Weeke ER, Kamper-Jørgensen F, Pedersen PA. Occurrence of bronchial asthma in the adult Danish population [in Danish]. Ugeskr Lag 1980;142:3272-4.

15 Samet JM. Epidemiologic approaches for the identification of asthma. Chest 1987;91(suppl):74-8.

16 Pedersen PA, Weeke ER. Epidemiology of asthma in Denmark. Chest 1987;91(suppl):107-14.

17 Peto R, Speizer FE, Cochrane AL, et al. The relevance in adults of air-flow obstruction, but not of mucus hypersection, to mortality from chronic lung disease. Am Rev Respir Dis 1983;128:491-500.

18 Huhti E, Takala J, Nuutinen J, Poukkula A. Chronic respiratory disease in rural men. Ann Clin Research 1978;10:87-94.

19 Higgins ITT. Respiratory symptoms, bronchitis, and ventilatory capacity in random sample of an agricultural population. Br Med J 1957;ii:1198-203.

20 Bartel W. Messungen Zur Staub-, Larm- und Geruchsbelastung an Arbeitsplatzen in der landwirtschaftlichen Produktion und Wege zur Entlastung. Grundl Landtechnik 1975;25:135-57.

21 Nilsson C. Dust investigations in pig houses [in Swedish, English summary]. Lund: Lantbruksuniversitet, 1982. (Report 25.)
22 Clark S, Rylander R, Larsson L. Airborne bacteria, endotoxin and fungi in dust, in poultry, and in swine confinement building. Am Ind Hyg Assoc J 1983;44: $537-41$

23 Donham K, Haglind P, Petersson Y, Rylander R. Environmental exposure and workers health in swine confinement buildings. Gothenburg: Swedish Environment Fund and University of Gothenburg, Department of Environmental Hygiene, 1986. (Report 3/86.)

24 Curtis SE, Drummond JG, Grunloh DS, Lynch PB, Jensen AH. Relative and qualitative aspects of aerial bacteria and dust in swine house. J Animal Sci 1975; 41:1512-20.

25 Anonymous. Støv og støvmåling $i$ svinestalde II. Bygholm Horsens: Statens Jordbrugstekniske Forsøg, 1986. (Orientering nr 43.)

26 Katila ML, Mantyjarvi RA, Ojanen TH. Sensitisation against environmental antigens and respiratory symptoms in swine workers. Br J Ind Med 1981;38:334-8.

27 Matson SC, Swanson MC, Reed CE, Yunginger JW. IgE and IgG mediated immune mechanisms do not mediate occupation related respiratory or systemic symptoms in hog farmers. J Allergy Clin Immunol 1983;72: 299-304.

28 Harries MG, Cromwell O. Occupational asthma caused by allergy to pig's urine. $\mathrm{Br} \mathrm{Med} J$ 1982;284:867.

29 Donham KJ, Rubino M, Thedell TD, Kammermeyer J. Potential health hazards to agricultural workers in swine confinement buildings. J Occup Med 1977;19: 383-7:

30 Church MK, Norn S, Pao GJ-K, Holgate ST. Non IgEdependent bacteria-induced histamine release from human lung and mast cells. Clin Allergy 1987;17: 341-53.

31 Chan-Yeung M, Chan H, Salari H, Wall ER, Tsye KS. Grain-dust extract induced direct release of mediators from human lung tissue. J Allergy Clin Immunol 1987; 80:279-84. 